\title{
The Effect of Customer Training in New Product Release: Empirical Evidence in The Banking Industry in Ghana
}

\author{
Article by Abena Pokuaa Ackah \\ Management, Texila American university, Ghana \\ E-mail: ackahabena@yahoo.com
}

\begin{abstract}
The study sought to investigate whether customer training in new product release will have an effect on customer loyalty. In this paper, we identify a wide-spread problem that confronts most bank customers through interviews and interactions with regards to using newly released products of the banks in Ghana. We sampled sixteen banks out of the thirty banks in Ghana using simple stratification and used simple random sampling to select 278 customers from the selected banks. Also, we interviewed 45 bank managers out of a target population of ninety (90). The models used were Pearson correlation coefficient to determine the strength of relationship between variables and linear regression to predict the effect of training customers in new product release on customer loyalty. The results show that customer training in new product enhances product usage, improves customer satisfaction, and impact positively on customer loyalty. We also suggest a training model and product satisfaction model to maximize the patronage of the new product.
\end{abstract}

Keywords: New product release, training, effect, customers, customer loyalty.

\section{Introduction}

The business environment of the banking industry has become highly competitive due to the rapid substitution of products and services as a result of technological advancement. Product advantage is short due to swift application of modern information technology to satisfy the market demands for new product. This has resulted in most banks offering almost the same products and services which come with accompanying challenges and difficulties. There is insufficient information and training on the use of these products. Therefore, the customer is unable to maximize the use of the products' functions to achieve the expected benefit which leads to extreme dissatisfaction.

When a bank releases a new product or product modification, it is necessary for the bank to deliver new training to its customers to facilitate product knowledge and usage. Lack of training customers in the product usage leads to customer frustrations in the use of the product which can cause frustrations leading to dissatisfaction for the new product. These frustrations coupled with some customers' complaints across the banks underpins the motivation to investigate this problem to give a deeper insight into the level of training banks provide for their customers with regards to new product release. Also, there is lack of scholarly works in this subject area creating a gap in repository of knowledge. Therefore, the study seeks to contribute to knowledge and also corroborate with empirical evidence the need for customer training in new products.

This article investigates the effect of customer training in new product release. It seeks to establish the relationship between training customers in the usage of a new product and customer loyalty. In particular, it finds answers to the level of training offered to customers when new products are released, customer satisfaction with new product usage, and staff reliability and responsiveness to customer needs. The effect of training customers in new product release will have the following impact as indicated in the diagram below: 
DOI: 10.21522/TIJMG.2015.SE.19.01.Art017

ISSN: 2520-310X

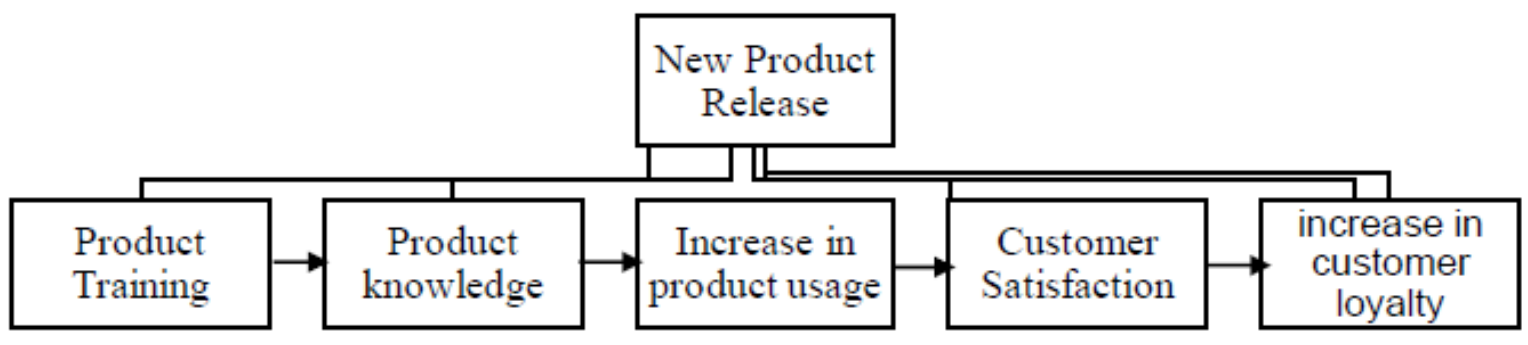

Figure 1. The impact of product training

Source: Ackah's construct (2018)

\section{Literature review}

\section{The concept of training}

The concept of training can be referred to as the art of imparting specific skills, abilities, and knowledge to employers, individuals, and groups. In other words, training has the capacity to inform and educate which is critical in making an informed decision. The businessdictionary.com defines training as a planned activity intended to impart information and/or instructions to improve the recipient's performance or to help him to attain a required level of knowledge or skill. To train is to develop one's skills, abilities and knowledge and therefore training and development synonymously go together with intertwining explanations.

A formal training is the art of imparting specific skills development and learning opportunities which are designed to help employees grow. "Training is teaching, or developing in oneself or others, any skills, and knowledge that relate to specific useful competence (https://en.wikipedia.org/wiki/training). This means the objective in training is to impart in one the capacity, productivity, and performance. Indeed, training is perceived as a critical tool in retaining customers. However, customers may not be well trained to use a new product if employees themselves lack knowledge in the training.

\section{The effects of training}

An effective training must seek to comprehend a number of elements such as customer persona, variations in usage, alternative products, competing products, customer objections and customer biases. Customer training is a way of building a good relationship such as the interpersonal relationship that can join parties together and offer benefit to each party. Thus, customer relationship should be seen from the perspective of emotional attachment and choice. For example, a customer attachment to a new product releases a continuous repeat purchase of that particular product making it difficult to switch. Therefore, training customers in the usage of new products will only seal the bond between the bank and the customer.

When customers are trained to use the new product, they acquire skills that help them to use the product to its fullest. This results in increase customer satisfaction leading to continuous product usage. The customers will engage in repeat purchase because of their capacity to use the product and this will lead to customer loyalty and advocates for the new product. The customers build a consistent trust and repose confidence in the use of a banks' subsequent products. Also, this makes the customers committed to the bank's products and services once their needs are met and they are getting the right customer experience. The repeat purchase allows the banks to achieve high customer retention leading to the rise in profitability.

\section{The concept of customer loyalty}

The concept of customer loyalty is one of the conduits for business growth. This is because once there is the existence of customer loyalty in the business it presupposes that customers are comfortable and happy to stay with the company; and they are most likely to repeat purchases leading to increase revenues with the positive effect of high levels of profitability. According to PR Loyalty solutions, (2011), "Customer 
loyalty is both attitudinal and behavioral tendency to favour one brand over all others due to satisfaction with the product or service, its convenience or performance, or simply familiarity and comfort with the brand". The group assert that behavioural loyalty is a situation where a person shops at two or more shops consistently which makes a person then becomes loyal to these shops.

Keimingham et al, (2005) cited in PR Loyalty Solutions (2011) also suggest that a person's loyalty in relation to purchases at any given time is subject to probability to purchasing brand $\mathrm{A}$ or $\mathrm{B}$ or $\mathrm{C}$ at a particular time and degree of purchase levels might also differ. Philip Kotler, (1991) also relates behavioural loyalty to product satisfaction. He affirms that consumers' dissatisfaction or satisfaction of a particular product is a stimulus to influence the degree of probability to purchase product A or B. This infers that when customers are satisfied with a product the probability of repeating such purchases are very high leading to customer loyalty. Customer loyalty is about the customers' deep commitment to the partial products and services and the consistent purchase of the brand or series of products and services belonging to the same brand (Oliver, 1997).

The other aspect of loyalty is attitudinal which focuses on psychological commitment where a person demonstrates a strong attachment to a brand who might be promoting to friends but does not necessarily purchase the brand regularly. According to Kotler, psychological commitment is a motivational issue that "arises from psychological states of tension such as the need for recognition, esteem, or belonging". He further explains human motivation in the perspectives of the psychologists' theories of human motivation such as, Sigmund Freud who assumes that the real psychological forces shaping peoples' behavior are largely unconscious; Abraham Maslow theory of motivation also attempts to explain why people are driven by particular needs at particular time; Herzberg's theory of motivation is a two factor theory of motivation which distinguishes factors that cause dissatisfaction from factors that cause satisfaction. There is a direct correlation between motivation and purchase behaviour and customers are most likely to repeat buying when they are adequately motivated through satisfaction.

\section{Determinants of customer loyalty}

Varying research findings have identified certain areas as determinants of customer loyalty. Crosby, (1979) sees quality as one of the areas that sustain customer loyalty. He defines quality as an elusive and indistinct construct, often mistaken for impressive adjectives like "goodness, or luxury, or shininess or weight, and its requirement are not easily articulated by consumers" (Takeuchi and Quelch, 1983). The explication and measurement of quality also present problems for researchers (Monroe and Krishman 1983) but quality is often associated with the products and services. It is the totality of the features and characteristics of a firm's products and services that have the capacity to satisfy customer's needs (Chavan, 2003).

Rodney and Williams (2004) conducted a study to identify the determinants of customer loyalty in Romania banking industry. The results show that customers are likely to retain their loyalty not only in the area of satisfaction but also factors such as attitudes towards customers, the level of trust customers have in the organization, and its employees' commitment and ability to ensure clients' financial interest. The study affirms that 58\% of switching behaviours are caused by high level of dissatisfaction with bank's pricing policy. This is in line with Herzberg's theory of motivation which talks about dissatisfaction factors that can undermine people's behaviour.

Further studies by Ndubusi, et al, (2009), Khalibi et al (2002) cited in Rania et al (2014) confirm the effect of perceived service quality, satisfaction, and trust as the main determinants that underpin the sustenance of customer loyalty. Additional past research studies confirm satisfaction, trust, commitment, involvement, perceived risk, habit, and switching cost as positively associated with customer loyalty. Indeed, the customer has a choice to choose from who they want to do business with; leading to the explosion in brand choices (Wiersema, 1994; Treacy, 1994) and increasing number of banks competing for attention for sustainability. 
DOI: 10.21522/TIJMG.2015.SE.19.01.Art017

ISSN: 2520-310X

The increasing need for satisfaction in banks' products is phenomenal, especially when the products are technologically driven. The only way to enhance the satisfaction of customers is to ensure that customers are knowledgeable about the products and comfortable with the usage. This is a requisite need to ensuring customer satisfaction and customer loyalty.

\section{Theoretical background and hypotheses development}

The demand for training customers in new product usage has become necessary due to the banks' continuous delivery of technologically driven products. Wells (2014) revealed in his research findings from Brandu Hall that many organisations do some sort of customer training dated back from (2012) in an attempt to retain customers. Wells also indicated that about $93 \%$ of companies that train their customers have seen increase in customer satisfaction and $88 \%$ increase in customer retention and suggests online training for customers to reduce cost.

Training has a strong effect on employee performance (Nassazi, 2013). Untrained employees are incapable of producing high-quality products and also lack the necessary knowledge and skills to provide quality customer experience which leads to customer dissatisfaction. Shaw (2017) stipulates that when companies train employees the rewarding effect is increased in productivity and profits. Thus, investing in employee training boost customer satisfaction and create more opportunities to generate new ideas for product development.

Training improves the performance of employees and especially when employees are trained well in product knowledge, they acquire the capacity to transfer the knowledge to customers that help them to maximize the effective use of the product's functions. Chung and Taylor (2016) in their article "The effectiveness of customer participation in new product development" affirm that the stage of customer participation will impact on new product innovativeness, speed to market, and new product financial level. Firm's reluctance to secure customer participation in product development may lead to customer dissatisfaction (Hoyer, et al. 2010).

There is a positive impact in return on investment (ROI) when firm consistently provide training in product knowledge. For example, Commvault company who had its customers involved in a specific training for one of its products reduced complaints calls from 7.5 calls to 6.5 calls and saved operating cost on the customer from $\$ 8,000$ to $\$ 5,000$ (Businessspectator.com). Training customers to use new product is very crucial because it influences product purchase and improve customer loyalty. We, therefore, propose the following hypotheses:

H1: Training customers in new product usage is positively associated with customer loyalty.

When customers are knowledgeable in the use of new products, they are able to maximize product utilization to obtain the expected benefit. Customer satisfaction is the key factor to determine long term customer retention which is mostly derived from product quality and the characteristics of service delivery. Researchers such as (Yi, 1990; Bastos and Gallego, 2008; and Chai et al, 2009) espouse the relationship between service and product quality as the key determinants of customer satisfaction. For this reason, we, propose the second hypothesis:

$\mathrm{H} 2$ : Customer satisfaction with new product usage is positively related to customer loyalty.

Reliability and responsiveness are some of the quality dimensions in facilitating customer satisfaction and retention particularly during the period of a new product release. The new product especially the technologically based product often presents challenges with its use. Customers may want to seek assistance from staff and therefore reliability and responsiveness of the staff are very crucial in determining customer's satisfaction in using the product. Iberahim et al. (2016) conducted a study on reliability and responsiveness of self-technology on retail banking service. The result showed that consistency, dependability, and timeliness are the most important factors that maximize customer faction. We, therefore, propose the third hypothesis:

H3: Staff reliability and responsiveness to customer need is positively related to customer loyalty. 
Consistent information release on new product creates greater awareness and also facilitate and stimulate desire for the product. The increase in awareness attracts more sales and it is largely attributed to consumers having adequate information on the product (Barroso, 2007). We therefore hypothesise that:

$\mathrm{H} 4$ : Consistent information release on new product is positively related to customer loyalty.

Consistent training can only impart knowledge and improves on learning experience. A bank that provides learning experience to help its customers to obtain the requisite skills maximize the use of its products to obtain the optimum benefits of the products. We therefore hypothesis that:

H5: Frequent training of customers is positively associated with customer loyalty.

The conceptual framework is indicated below:

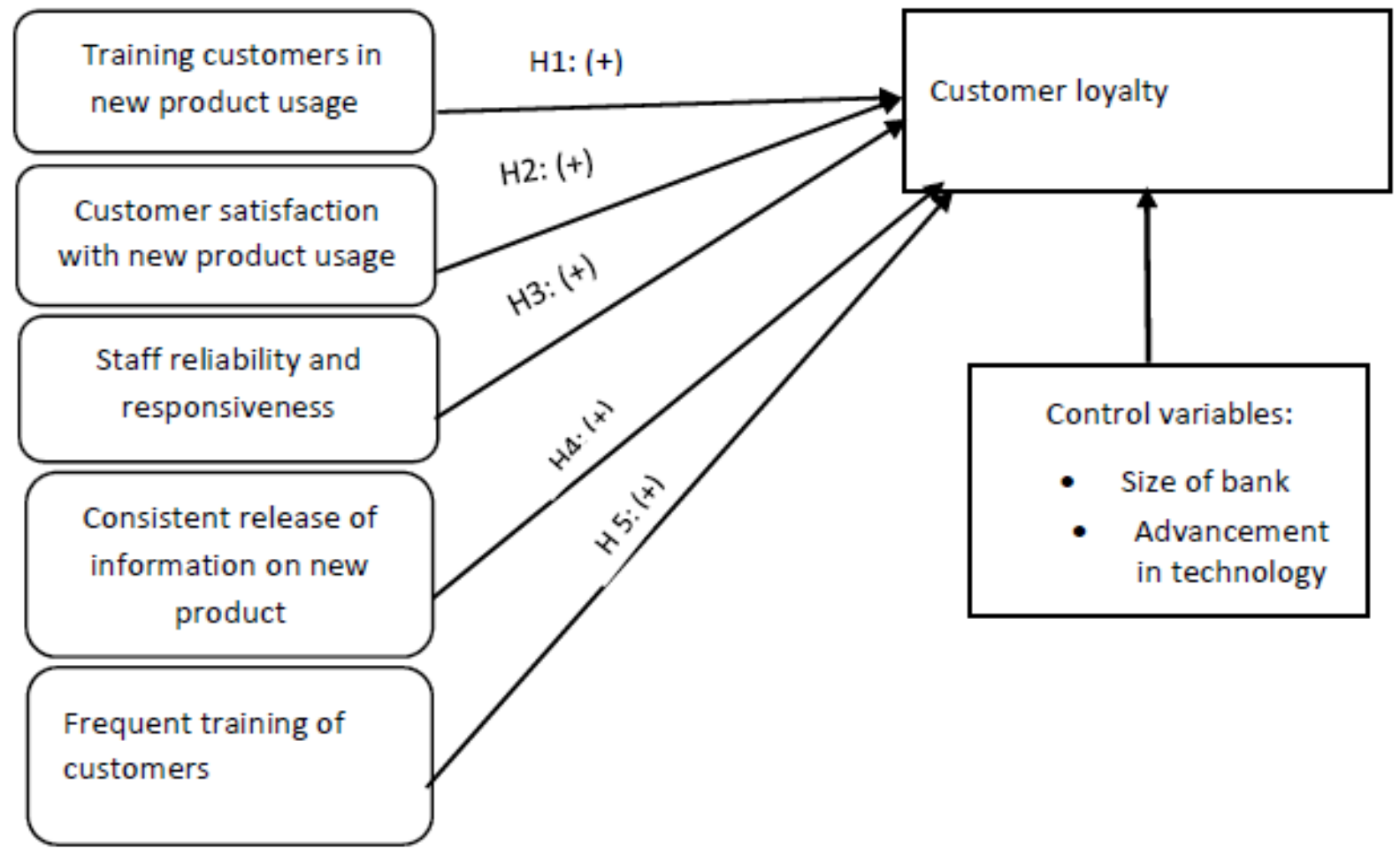

Figure 2. Conceptual framework

\section{Research methodology}

\section{Design}

The study adopted both descriptive and inferential methodologies. The descriptive method provides description and characteristics of the issues and inferential method, on the other hand, provides a deeper understanding of the issues relating to training needs of customers. With this method, we make predictions with specific conclusions based on the findings of the study.

\section{Sampling}

We used simple stratification to select the banks and used purposive sampling to select managers from the population of the commercial banks. There are thirty (31) banks in Ghana and sixteen (16) banks were selected representing 53\% of the banks' population, to take part in the study. This is because they are all commercial banks. The target population for management was ninety (90) and 45 was sampled representing $50 \%$ of the population. 
DOI: 10.21522/TIJMG.2015.SE.19.01.Art017

ISSN: 2520-310X

However, with regards to the customers, we adopted simple random sampling in selecting the population of the customers from each bank. The target population is thousand $(1,000)$ which is infinite and we adopt the formula of (Krejcie \& Morgan, 1970) to determine the sample size as indicated:

$\mathrm{S}=\frac{x^{2} N P(1-P)}{d^{2}(N-1)+x^{2} P(1-P)}$

Where:

$S=$ Required Sample size

$X=Z$ value is 1.96 for $95 \%$ confidence level

$N=$ Population Size

$P=$ Population proportion is $50 \%$ expressed as decimal

$0.5 d=$ Degree of accuracy (5\%), expressed as a proportion (.05); It is margin of error

$\mathrm{S}=\frac{1.96^{2} X 1,000 \times 0.5(1-0.5)}{.05^{2}(1,000-1)+1.96^{2} X 0.5(1-0.5)}$

We simplify the process of determining the sample size for a finite population of $(1,000)$ by adopting the table of Krejcie \& Morgan (1970) as indicated:

Table 1. Table for determining sample size

\begin{tabular}{|c|c|c|c|c|c|c|c|c|c|}
\hline \multicolumn{10}{|l|}{ Table 3.1} \\
Table for Determining Sample Size of a Known Population \\
\hline $\mathbf{N}$ & $\mathbf{S}$ & $\mathbf{N}$ & $\mathbf{S}$ & $\mathbf{N}$ & $\mathbf{S}$ & $\mathbf{N}$ & $\mathbf{S}$ & $\mathbf{N}$ & $\mathbf{S}$ \\
\hline 10 & 10 & 100 & 80 & 280 & 162 & 800 & 260 & 2800 & 338 \\
\hline 15 & 14 & 110 & 86 & 290 & 165 & 850 & 265 & 3000 & 341 \\
\hline 20 & 19 & 120 & 92 & 300 & 169 & 900 & 269 & 3500 & 346 \\
\hline 25 & 24 & 130 & 97 & 320 & 175 & 950 & 274 & 4000 & 351 \\
\hline 30 & 28 & 140 & 103 & 340 & 181 & 1000 & 278 & 4500 & 354 \\
\hline 35 & 32 & 150 & 108 & 360 & 186 & 1100 & 285 & 5000 & 357 \\
\hline 40 & 36 & 160 & 113 & 380 & 191 & 1200 & 291 & 6000 & 361 \\
\hline 45 & 40 & 170 & 118 & 400 & 196 & 1300 & 297 & 7000 & 364 \\
\hline 50 & 44 & 180 & 123 & 420 & 201 & 1400 & 302 & 8000 & 367 \\
\hline 55 & 48 & 190 & 127 & 440 & 205 & 1500 & 306 & 9000 & 368 \\
\hline 60 & 52 & 200 & 132 & 460 & 210 & 1600 & 310 & 10000 & 370 \\
\hline 65 & 56 & 210 & 136 & 480 & 214 & 1700 & 313 & 15000 & 375 \\
\hline 70 & 59 & 220 & 140 & 500 & 217 & 1800 & 317 & 20000 & 377 \\
\hline 75 & 63 & 230 & 144 & 550 & 226 & 1900 & 320 & 30000 & 379 \\
\hline 80 & 66 & 240 & 148 & 600 & 234 & 2000 & 322 & 40000 & 380 \\
\hline 85 & 70 & 250 & 152 & 650 & 242 & 2200 & 327 & 50000 & 381 \\
\hline 90 & 73 & 260 & 155 & 700 & 248 & 2400 & 331 & 75000 & 382 \\
\hline 95 & 76 & 270 & 159 & 750 & 254 & 2600 & 335 & 1000000 & 384 \\
\hline Note: Nis Population Size; S is Sample Size & & & Source: Krejcie \& Morgan 1970 \\
\hline
\end{tabular}

Therefore, the sample size needed for the population of thousand $(1,000)$ is $\mathbf{2 7 8}$

Table 2. Distribution of target population and sample

\begin{tabular}{|l|l|l|l|}
\hline Group & Target population & Sample size & percentage \\
\hline Banks & 30 & 16 & 53 \\
\hline management & 90 & 45 & 50 \\
\hline Customers & 1,000 & 278 & 28 \\
\hline Total & 1,120 & 298 & 44.44 \\
\hline
\end{tabular}




\section{Data collection}

The preparatory stage saw the training and education of field workers on how to interview the management and customers to elicit proper responses for investigation. The second stage was the design of the questionnaire which went through an iterative process and pilot testing with the customers before the final design of the questionnaire. This was to ensure that the final questionnaire answers the research questions. We applied closed-ended questions and five-point Likert scale type questions to elicit responses from the respondents. The questionnaires were randomly distributed to the sampled 278 customers across the sixteen banks. We also had face-face interviews with some of the managers across the selected banks to elicit their views on new product training and to determine whether it is incorporated in the integral part of the bank's strategy to ensure maximum product usage.

\section{Measures}

The information gained from the survey allowed us to measure dependent variables, independent variables, and control variables.

\section{Dependent variable}

The dependent variable is the customer loyalty which reflects the results of customers' response to the new product during the period. The level of customers' complaints about the new product is analyzed as well as the level of product usage.

\section{Independent variables}

Lack of training in new product release is associated with negative effect on customer loyalty. This was measured on a five point-Likert scale ranging from 1 to 5 . A higher value signifies a higher level of training in new product release.

Customer satisfaction is expressed as customers being satisfied with the new product usage, meeting their expectations and expected benefit. These were measured using the five-point Likert scale ranging from 1 to 5. A higher value signifies a higher level of training in new product release.

Staff reliability and responsiveness is directly related to service quality tangibles. It is defined as the consistency in performing the promised service dependably, accurately, and consistently. The bank's responsiveness and willingness to help customers in the new product usage. Areas like accessibility, availability, and willingness to help were measured using 5 point-Likert scale with the highest score representing high level of reliability and responsiveness.

\section{Control variable}

The size of a firm is an important element in its performance. It affects the firm's operations and performance and the key characteristic of a larger firm is the ability to exploit economics of scale for their advantage (Dut, 2015). These firms have an effective implementation in operations and therefore return on investment is relatively higher. It is, therefore, necessary to make distinction between the larger banks and the smaller banks, the level of IT infrastructure, and their capacity to deliver training to their customers.

\section{Model specification}

The models allowed us to test the hypotheses of the study. The study made use of Pearson correlation coefficient to test the strength of relationship of the independent variables - lack of training in new product release, customer satisfaction with new product usage, staff reliability and responsiveness, and customer loyalty - the dependent variable. The degree of relationship is expressed by the coefficient ranging between $(-1 \leq \mathrm{r} \geq+1)$. Pearson correlation coefficient equation is indicated below:

$$
\begin{gathered}
\mathrm{r}=\cap(\boldsymbol{\Sigma} \times \boldsymbol{\gamma}-)(\boldsymbol{\Sigma} \times)(\boldsymbol{\Sigma} \boldsymbol{\gamma}) \quad \text { equa (1) } \\
\sqrt{\left(\cap \Sigma \boldsymbol{x}^{2-(\Sigma \times) 2}\right)\left(\cap \boldsymbol{\Sigma} \boldsymbol{\gamma}^{2}-(\boldsymbol{\Sigma} \boldsymbol{\gamma}) \mathbf{2}\right)}
\end{gathered}
$$


DOI: 10.21522/TIJMG.2015.SE.19.01.Art017

ISSN: 2520-310X

Where:

$\mathrm{N}=$ number of pairs of scores

$\Sigma \mathrm{Xy}=$ sum of the products of paired scores

$\Sigma X=$ sum of scores

$\Sigma y=$ sum of scores

$\Sigma \mathrm{x}^{2}=$ sum of squared $\mathrm{X}$ scores

$\Sigma y^{2}=$ sum of squared y scores

The study also made use of linear regression technique methods to ascertain the best-fitted model for estimating and predicting the effect of training in new product release. The dependent variable is customer loyalty and the independent variables are lack of training in new product release, customer satisfaction with new product usage, staff reliability and responsiveness to customer need with regard to new product usage, frequent training in new product, and information on new product release. The following model was used to examine the effect of the independent variables on customer loyalty. The equations and variables to be used are given below:

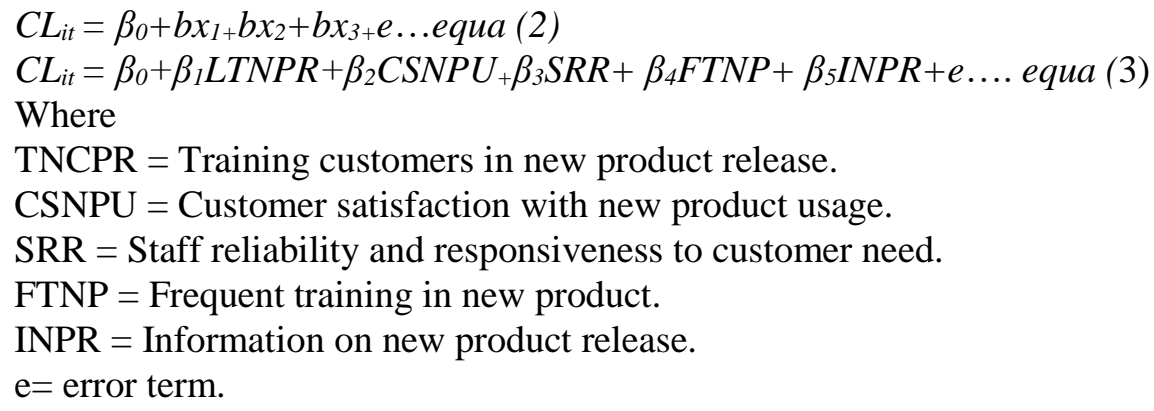

The (e) is the confidence interval which means we tested each variable at $5 \%$ level of significance in other words we used $95 \%$ confidence level.

\section{Empirical results}

\section{Descriptive statistics and correlation test}

The descriptive statistics below indicate the closeness of individual response to the question asked. The spread of the responses is concentrated around the mean signifying the uniformity in the response rate. It also reflects the closeness of the individual data values from the mean value and underscores a true reflection of the equivalence of the sample mean to the mean of the overall population. For example, training in new product usage has a mean of 4.10 and a standard deviation of .866. Similarly, information on new product release has a mean of 4.17 and a standard deviation of .849 . These indicators corroborate the assertion of uniformity in the response rate.

\section{Descriptive}

\begin{tabular}{|l|l|l|l|l|l|l|l|l|l|}
\hline Variables & Mean & $\begin{array}{l}\text { Std. } \\
\text { Error of } \\
\text { Mean }\end{array}$ & Median & Mode & $\begin{array}{l}\text { Std. } \\
\text { Deviatio } \\
\mathrm{n}\end{array}$ & $\begin{array}{l}\text { Varian } \\
\text { ce }\end{array}$ & Range & $\begin{array}{l}\text { Mini } \\
\text { mum }\end{array}$ & $\begin{array}{l}\text { Maxim } \\
\text { um }\end{array}$ \\
\hline $\begin{array}{l}\text { Frequent } \\
\text { training in } \\
\text { new product }\end{array}$ & 1.65 & 0.029 & 2.00 & 2 & 0.477 & 0.228 & 1 & 1 & 2 \\
\hline $\begin{array}{l}\text { Information } \\
\text { on new } \\
\text { product } \\
\text { release }\end{array}$ & 4.17 & 0.051 & 4.00 & 4 & 0.849 & 0.721 & 4 & 1 & 5 \\
\hline
\end{tabular}




\begin{tabular}{|l|l|l|l|l|l|l|l|l|l|}
\hline $\begin{array}{l}\text { Training in } \\
\text { new product } \\
\text { usage }\end{array}$ & 4.10 & 0.052 & 4.00 & 4 & 0.866 & 0.751 & 4 & 1 & 5 \\
\hline $\begin{array}{l}\text { Customer } \\
\text { Satisfaction } \\
\text { with new } \\
\text { product } \\
\text { usage }\end{array}$ & 4.06 & 0.053 & 4.00 & 4 & 0.889 & 0.790 & 4 & 1 & 5 \\
\hline $\begin{array}{l}\text { Responsiven } \\
\text { ess And } \\
\text { reliability }\end{array}$ & 4.02 & 0.061 & 4.00 & 4 & 1.025 & 1.050 & 4 & 1 & 5 \\
\hline
\end{tabular}

Correlations

\begin{tabular}{|c|c|c|c|c|c|c|}
\hline Variables & & $\begin{array}{l}\text { Regular } \\
\text { training of } \\
\text { customers }\end{array}$ & $\begin{array}{l}\text { Informatio } \\
\mathrm{n} \text { on new } \\
\text { product } \\
\text { release }\end{array}$ & $\begin{array}{l}\text { Training } \\
\text { customers } \\
\text { in product } \\
\text { usage }\end{array}$ & $\begin{array}{l}\text { Satisfaction } \\
\text { with product } \\
\text { usage }\end{array}$ & $\begin{array}{l}\text { Responsive } \\
\text { ness and } \\
\text { reliability of } \\
\text { staff }\end{array}$ \\
\hline \multirow{2}{*}{$\begin{array}{l}\text { Regular } \\
\text { training of } \\
\text { customers. }\end{array}$} & $\begin{array}{l}\text { Pearson } \\
\text { Correlation }\end{array}$ & 1 & 0.042 & 0.53 & 0.045 & 0.094 \\
\hline & $\begin{array}{l}\text { Sig. (2- } \\
\text { tailed) }\end{array}$ & & 0.483 & 0.375 & 0.456 & 0.118 \\
\hline \multirow{2}{*}{$\begin{array}{l}\text { Release of } \\
\text { information } \\
\text { on new } \\
\text { product }\end{array}$} & $\begin{array}{l}\text { Pearson } \\
\text { Correlation }\end{array}$ & 0.042 & 1 & $.623^{* *}$ & $.483^{* *}$ & $.527^{* * *}$ \\
\hline & $\begin{array}{l}\text { Sig. (2- } \\
\text { tailed) }\end{array}$ & 0.483 & & 0.000 & 0.000 & 0.000 \\
\hline \multirow{2}{*}{$\begin{array}{l}\text { Training } \\
\text { customers in } \\
\text { product usage }\end{array}$} & $\begin{array}{l}\text { Pearson } \\
\text { Correlation }\end{array}$ & 0.53 & $0.623^{* *}$ & 1 & $0.563^{* *}$ & $0.551^{* *}$ \\
\hline & $\begin{array}{l}\text { Sig. (2- } \\
\text { tailed) }\end{array}$ & 0.375 & 0.000 & & 0.000 & 0.000 \\
\hline \multirow{2}{*}{$\begin{array}{l}\text { Satisfaction } \\
\text { with product } \\
\text { usage }\end{array}$} & $\begin{array}{l}\text { Pearson } \\
\text { Correlation }\end{array}$ & 0.045 & $0.483^{* *}$ & $0.563^{* *}$ & 1 & $0.649^{* *}$ \\
\hline & $\begin{array}{l}\text { Sig. (2- } \\
\text { tailed) }\end{array}$ & 0.456 & 0.000 & 0.000 & & 0.000 \\
\hline \multirow{2}{*}{$\begin{array}{l}\text { Responsivenes } \\
\mathrm{s} \text { and } \\
\text { reliability of } \\
\text { staff }\end{array}$} & $\begin{array}{l}\text { Pearson } \\
\text { Correlation }\end{array}$ & 0.094 & $0.527^{* *}$ & $0.551^{* *}$ & $0.649^{* *}$ & 1 \\
\hline & $\begin{array}{l}\text { Sig. (2- } \\
\text { tailed) }\end{array}$ & 0.118 & 0.000 & 0.000 & 0.000 & \\
\hline
\end{tabular}

There is a significant correlation between the variables. For example, information release on a new product, training in new product usage, satisfaction with product usage, and responsiveness and reliability of staff show a correlation of $\mathrm{r}=(+) .623$ indicating strong correlation, $\mathrm{r}=(+) .483$ indicating weak correlation and $\mathrm{r}=(+) .527$ showing some degree of correlation respectively in the variables. The implication is that as information is released on new product there is a corresponding increase in product usage training, staff responsiveness and reliability in providing help to customers also increase, and there is increase in customers experience satisfaction in the product usage. 
DOI: 10.21522/TIJMG.2015.SE.19.01.Art017

ISSN: 2520-310X

Training customers in new product usage, information release on new product, satisfaction with new product usage, responsiveness, and reliability of staff are positively correlated and show a strong correlation of $\mathrm{r}=(+) .623, \mathrm{r}=(+) .563$, and $\mathrm{r}=(+) .649$ respectively demonstrating the strength of relationship between the variables. As training in product usage increases, there is a corresponding increase in product satisfaction and responsiveness and reliability of staff in responding to customers' challenges on the new product usage. There is a clear indication that a new product release is positively associated with training the customers on product usage which relates to customer satisfaction in the new product.

\section{Regression estimates}

$*$, ** and $* * *$ denotes $10 \%, 5 \%$ and $1 \%$ significance levels respectively

The analysis of variance (ANOVA) shows a P-value of .000 which is less than .05 . This indicates that $\mathrm{P}$ $<.05$ at .000 significance depicts a strength of evidence to accept the hypotheses that customer training in new product improves customer loyalty. The low R-squared values represent a higher difference between the observed data and the fitted values indicating no relationship between the predictors and the dependent variable. Specifically, variables such as, training in product usage, satisfaction with product usage, responsiveness and reliability of staff have p-values of .005, .001, and .000 demonstrating high effect on customer loyalty and provide a strong evidence to accept the hypotheses.

However, the coefficient of regular training of customers has a standard error of .042, t- statistics of .211, and $\mathrm{P}$ - value of .833 . Therefore, the probability value is greater than .05 . That is a $\mathrm{P}$ - value of $.833>.05$ which provides a strong evidence that regular training of customers does not lead to customer loyalty. Similarly, the coefficient of consistent release of information has a standard error of .031, $t$ statistics of .657 , and a P-value .511> .05 indicating that consistent information release on new products does not lead to customer loyalty.

The predictable variables that had p-values of $.005, .001$, and .000 provide a strong evidence that the hypotheses must be accepted. This is an indication that banks should provide some form of training to their customers in the usage of new products to increase customer satisfaction and loyalty. This training is a form of customer service that will affect customer satisfaction and loyalty which is in line with Yarimoglu, (2011), whose study affirmed the effect of customer service on customer loyalty.

\section{Bank managers response to product usage training for customers}

We had personal interviews with the forty-five (45) managers across the selected banks and it was observed that ten (10) out of the forty-five (45) representing $22.22 \%$ seems to be sure of formal training arrangement for customers on new product release. These managers are coming from the top ten banks who seemingly have the resources and capacity to make such arrangements available to their customers. Twenty (20) of the managers representing $44.44 \%$ thought that customers who come to the banking hall to seek for help in the usage of new product and are helped, is perceived by the majority of the managers as a form of training to their customers. These managers fall in the category of the average performing banks whose resources are relatively lesser than the best performing banks. Fifteen (15) managers representing 33.33\% were not sure or confident of any specific training to customers. These are smaller banks who neither have a large resource base nor the capability to meet the challenges that accompany such training.

\section{Management implications and training model for banks}

In delivering training to customers, management must release the needed resources to ensure quality training and knowledge sharing on the new product. What is most significantly needed is the capacity to develop training content against tight timelines and process delivery. Management must ensure that employees are trained at all levels taking cognizance of their tight schedule, varying their needs and making sure they are equipped with sufficient information about the new product.

The sales and marketing team have a different perspective in dealing with the customers. Their main concerns are mostly closing the sales and may not be necessarily interested in the technical details. But, once they interact with the customers, they need to be trained not only on the features and benefits of the 
product but its usage as well. Management must ensure greater emphasis on buyer personas when training this group but more importantly, the focus should also be on technical details as well. This is to provide the opportunity to train customers on product usage on site.

The support team must be well trained in the new product to enhance their day-to-day customer support and answering of calls on the new product release. They must show competence in responding to customers questions on product usage and this is possible if the team has sufficient knowledge about the product usage. The support team must have good telephone etiquette so that customers can easily understand the issues involved.

Good business etiquette is an important characteristic in facilitating good business relations that can help the banks to attract more customers. Specifically, the art of demonstrating good telephone etiquette must be incorporated into the training programmes of the banks. Well-trained support team, staff, branch staff, and sales team must be polite in their daily interaction with the customers. Important phrases like "please", "thank you" and "you are welcome" are phrases that underpin the characteristics of politeness and should not depart from the words that they alter; especially when they have to offer help to customers.

Additionally, the banks must develop a customer focus website where information on new product release, product modification, and product augmentation can be announced. Indeed, the use of social media as an engagement tool will facilitate effective customer engagements. The banks can transform consistent online conversations with customers into analyzed data for useful use. The use of digital technologies can provide more value to customers as a result of customers receiving more useful and relevant information on new products. The banks training trail is indicated below:

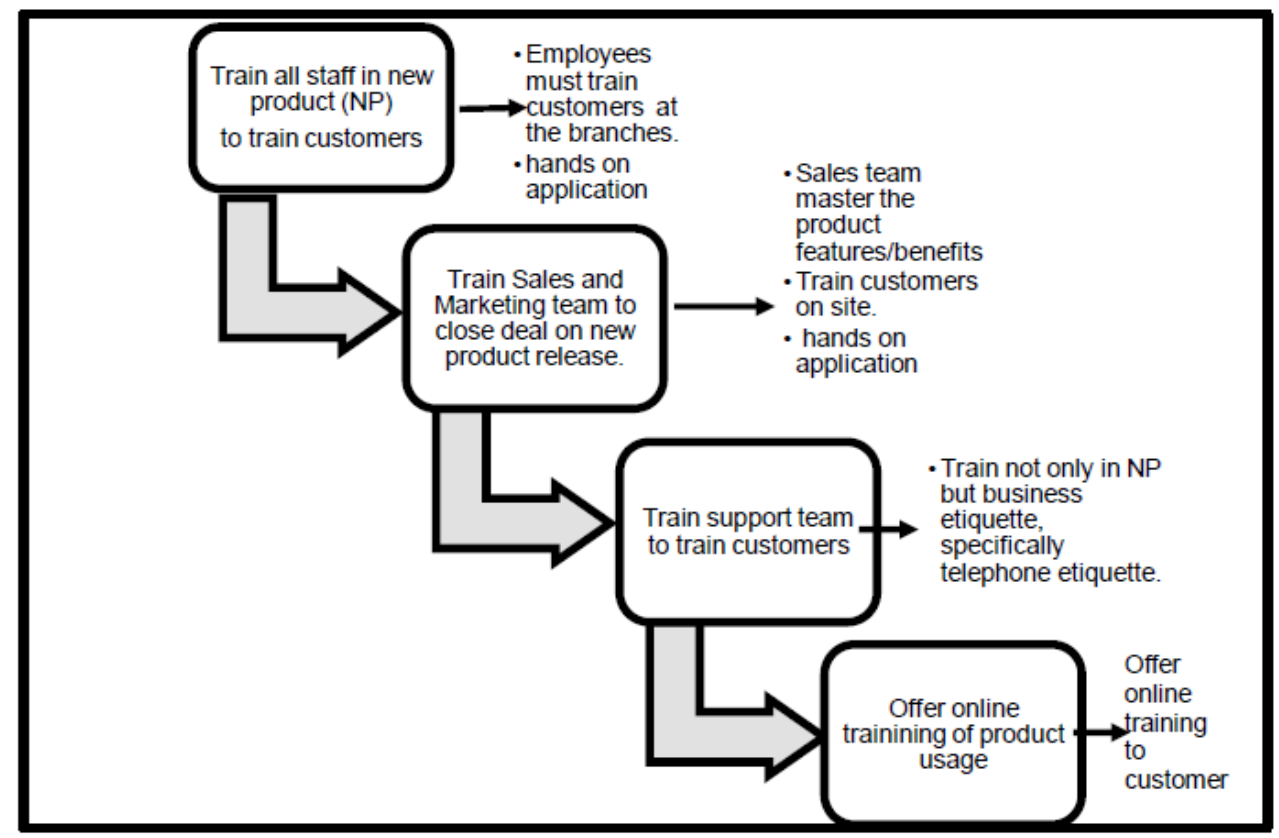

Figure 3. Customer training model

Source: Ackah's Construct, (2018)

\section{Measuring customer satisfaction for new product use}

It is important to ascertain whether the product usage/service achieved customer satisfaction. In this regard, regular customer surveys to measure customer satisfaction with the usage of the new product is necessary. All complaints about the product usage across the bank should be retrieved from the support centres on weekly basis to determine the levels of customer complaints. Specifically, the complaint analysis 
DOI: 10.21522/TIJMG.2015.SE.19.01.Art017

ISSN: 2520-310X

should identify gaps in the product usage and provide adjustment and strategies needed to address customers' complaints as indicated in the product satisfaction model:

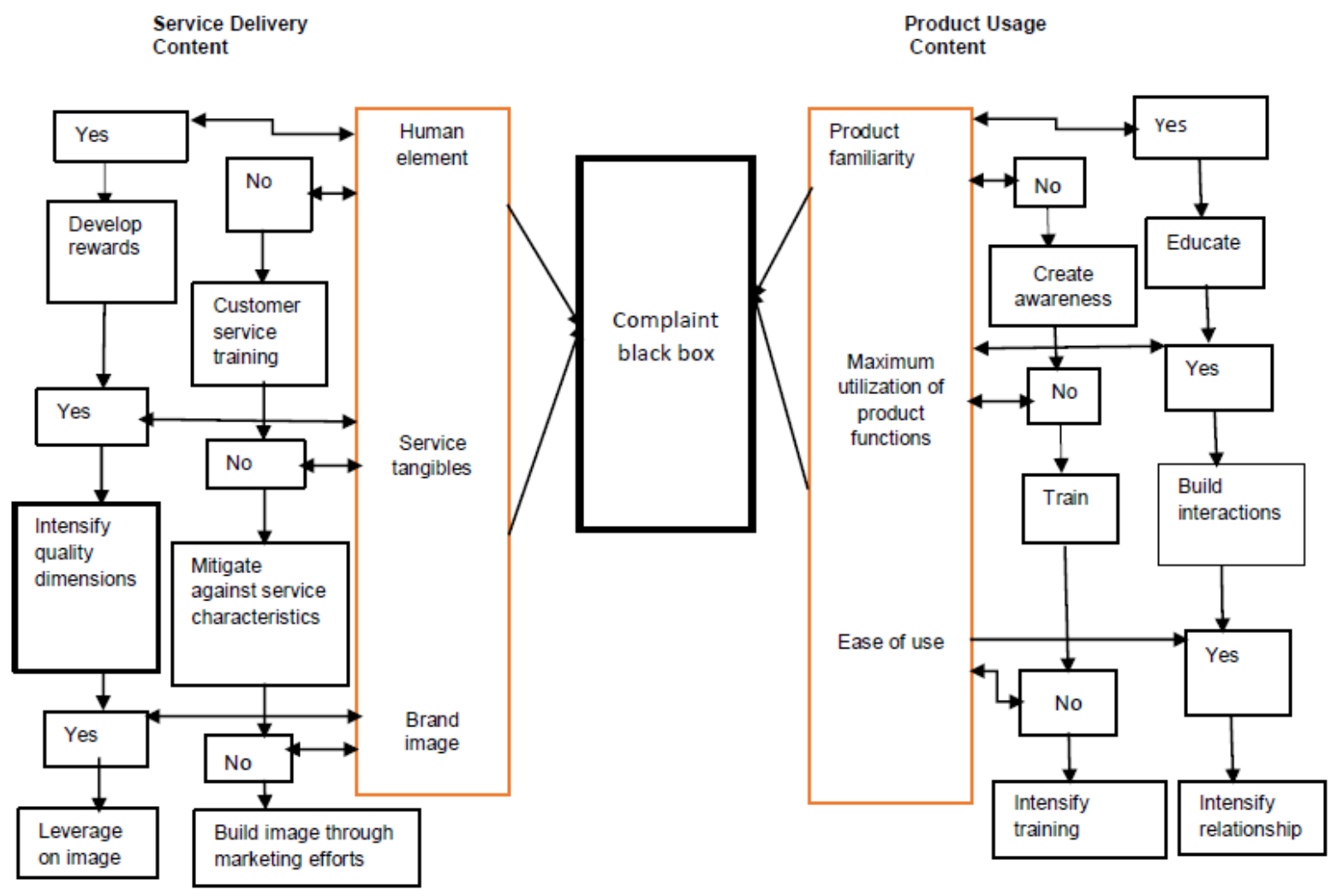

Figure 4. Product Satisfaction Model

Source: Ackah's Construct, (2018)

The model represents the customer complaint black box that receives information from the two key dependent variables; product usage content and service delivery content. The former measures product familiarity, maximum utilization of product function, and ease of use, while the latter measures the human element, service tangibles, and brand image of the product. A "no" box indicates negative response which is a gap and needs to be closed; a "yes" box indicates positive response and strategies to consolidate the position. The model depicts that any gap that is identified should provide re-adjustment and strategies to close the gap and if the response is a "yes", the model provides strategies to sustain the position. Different strategies are suggested to facilitate customer training and monitoring in new product usage.

Other metrics to ascertain product satisfaction are the regular analysis of sales revenues on the product against existing ones; a periodic monitoring of the product sales to establish a trend analysis using time series; a regular review of customer database to ascertain the effect of customer training in the new product on customer retention and customer loyalty.

\section{Conclusion}

In conclusion, the technological advancement is the key reason why products are changing rapidly and the need to communicate the change to customers has become very crucial. Unfortunately, most banks do not give much attention to training customers on new products because of the cost involved. But the understanding is how to create an effective team to interact with customers; and the ability to identify perennial aspects of the product training; and equipping the teams with an essential understanding in order to cut down cost without necessitating a repeat product training. 
The research study has shown that training customers in new product release will not only improve customer satisfaction but increase customer loyalty. When customers are comfortable in using new products there is a repeat purchase of the product and thus increase the sales of the product. The repeat purchase leads to customer loyalty, increases sales revenues, and overall profitability.

\section{Recommendation}

This study needs further empirical research into the effects of training customers in new product release. Also, there is lack of scholarly works in this subject area and more empirical studies are needed to contribute to the expansion of knowledge in this area.

\section{References}

[1]. Amo, T. (2017). The negative effect of lack of training in the workplace. Retrieved from:http://smallbusiness.chron.com/negative-effects-lack-training-workplace-45171.html.

[2]. Alicia Barroso, (2007). Advertising and Consumer Awareness of a New Product. Job Market Paper, November 2007. Retrieved from: http://ftp.zew.de/pub/zew-docs/veranstaltungen/rnic/papers/AliciaBarroso.pdf.

[3]. Bastos, J.A.R., and Gallego, P.M. (2008). Pharmacies Customer Satisfaction and Loyalty: A Framework Analysis. Journal of Marketing. Universal de Salamanca

[4]. Chai, K.H., Ding, Y., and Xing, Y. (2009). Quality and Customer Satisfaction Spillovers in the Mobile Phone Industry Service. Science: (2), pp. 93-106.

[5]. Crosby, P. (1979). Quality is Free. New York: McGraw-Hill. ISBN 0-07-014512-1.

[6]. Chavan, R.B. (2003). "Manual on Quality Assurance for Khadi". Mahatma Gandhi Institute of Rural Industrialization, a collaborative project of KVIC \& IITD.

[7]. Dut, V.V. (2015). The Effects of Local Business Environments on SMEs' Performance: Empirical Evidence from the Mekong Delta. Asian Academy of Management Journal. Vol.20.N0. 1. 101-122. 2015.

[8]. Filip, A. and Angel D.L. (2009). Customer Loyalty and its determinants in a Banking Services Environment. The Bucharest Academy of Economic Studies, Romania. Vol XI. Nr.26. June 2009.

[9]. Iberahim H.; Mohd Taufik, N.K.; Mohd Adzmir.; and Saharuddin, H. (2016). Customer Satisfaction on Reliability and Responsiveness of Self -Service Technology for Retail Banking Services. Procedia Economics and Finance 37:13-20 • December 2016 DOI: 10.1016/S2212-5671(16)30086-7.

[10]. Kotler, P. (1991). Marketing Management: Analysis, Planning, Implementation, and Control. Prentice-Hall, Inc. Englewood Cliffs, N.J. 07632. $7^{\text {th }}$ edition, pp. 173-178.

[11]. Lagrosen, S. (2005). Customer Involvement in New Product Development: A Relationship Marketing Perspective. DOI: 10.1108/14601060510627803. Retrieved from: https://www.researchgate.net/publication/235321071_Customer_involvement_in_new_product_development._A_rel ationship_marketing_perspective.

[12]. Nassazi, (2013). Effects of Training on Employee Performance: Evidence from Uganda. Business Economics and Tourism. Retrieved from:

https://publications.theseus.fi/bitstream/handle/10024/67401/THESIS.pdf?sequence=1.

[13]. Oliver, R.L. (1997). Satisfaction: A Behavioural Perspective on the Consumer. New York: McGraw-Hill.

[14]. Rana, H., Aur, K., and Hammed, M. S. (2014). Determinants of Customer Loyalty: Evidence from the Egyptian Mobile Market. International Journal of Customer Relationship Marketing and Management.

[15]. Woojung, C. and Steven, A.T. (2016). The Effectiveness of Customer Participation in New Product Development: Ameta-Analysis. Journal of Marketing, 80 (1), 47-64. https://www.talentlms.com/elearning/producttraining.

[16]. Shaw, J. (2017). "Effects of Training on Employee Performance" Retrieved from: smallbusiness.chrron.com/effects-training-employee-performance-39737.html.

[17]. Wells, D. (2014). Retrieved from: http://www.inc.com/donna-wells/when-it-comes-tocustomers-train-toretrain.html.

[18]. Yi, Y. (1990). A critical Review of Consumer Satisfaction in Zeithaml. V. (Ed), Review of Marketing, 1990, American Marketing Association, Chicago, IL, pp. 68-123. 
DOI: 10.21522/TIJMG.2015.SE.19.01.Art017

ISSN: 2520-310X

[19]. Yarimoglu, E. (2011). Customer Service Effects on Customer Satisfaction and Customer Loyalty: A Field Research in Shopping Centers in Izmir City - Turkey. International Journal of Business and Social Science. 2. 